\section{Evaluation by molecular docking of inhibitors of the enzyme pteridine reductase 1 from Leishmania}

\author{
Avaliação por acoplamento molecular de inibidores da enzima pteridina redutase 1 de Leishmania
}

Evaluación del acoplamiento molecular de los principales inhibidores de la pteridina reductasa 1

\begin{abstract}
Joabe Lima Araújoํㅜ, Ruan Sousa Bastos ${ }^{1}$, Gardênia Taveira Santos², Jessé Lima Araújo ${ }^{1}$, Jefferson Almeida Rocha $^{1}$
\end{abstract}

\footnotetext{
${ }^{1}$ Universidade Federal do Maranhão, Department of Natural Sciences/Chemistry, Grajaú, Maranhão, Brazil.

2 Universidade Estadual do Maranhão, Nursing Department, Colinas, Maranhão, Brazil.
}

\begin{abstract}
Objective: The objective of this work is to perform a bioactive analysis of Leishmania major Pteridine Reductase 1 inhibitors (LmPTR1) through in silico molecular docking studies. Method: The receptor and the ligands were prepared using CHIMERA v. 13.1 suppressing all waste. The Lamarckian Genetic Algorithm (LGA) with global search and pseudo-Solis and Wets with local search, were the methods used in molecular docking. Each simulation consisted of 100 independent runs. The rest of the parameters were set to default values. Results: The main molecular interaction between the ligand and the receptor obtained $-7.05 \mathrm{kcal}_{\text {.mol }}^{-1}$ of binding energy for the paromomycin, however the highest inhibition constant was obtained between the simulation of miltefosine with the receptor, obtaining $58.21 \mu \mathrm{M}$ of inhibition constant. Conclusion: The results reveal a reduced efficacy of the four drugs tested in this study against Leishmaniasis, thus highlighting the need for novel bioactive antileishmania alternatives.
\end{abstract}

Descriptors: Leishmaniasis; Molecular Biology; Molecular Docking Simulation.

\section{RESUMO}

Objetivo: O objetivo deste trabalho foi realizar uma análise bioativa dos inibidores da Leishmania major Pteridine Reductase 1 (LmPTR1) através de estudos de acoplamento molecular in silico. Método: O receptor e os ligantes foram preparados usando CHIMERA v. 13.1 suprimindo todos os resíduos. O algoritmo genético lamarckiano (AGL) com busca global e pseudo-Solis e Wets com busca local foram os métodos utilizados no encaixe molecular. Cada simulação consistiu em 100 corridas independentes. O restante dos parâmetros foi definido para os valores padrão.

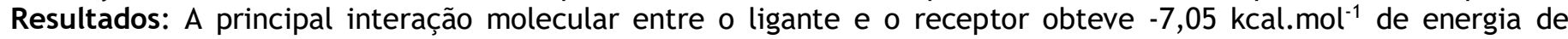
ligação para a paromomicina, porém a maior constante de inibição foi obtida entre a simulação de miltefosina com o receptor, obtendo 58,21 $\mu \mathrm{M}$ de constante de inibição. Conclusão: Os resultados revelam uma eficácia reduzida dos quatro medicamentos testados neste estudo contra a leishmaniose, destacando a necessidade de novas alternativas bioquímicas contra a leishmaniose.

Descritores: Leishmaniose; Biologia Molecular; Simulação de Acoplamento Molecular.

\section{RESUMÉN}

Objetivo: El objetivo de este trabajo fue realizar un análisis bioactivo de los inhibidores de Leishmania major Pteridine Reductase 1 (LmPTR1) mediante estudios de acoplamiento molecular in silico. Método: El receptor y los ligandos se prepararon usando CHIMERA v. 13.1 suprimiendo todos los desechos. El algoritmo genético lamarckiano (AGL) con búsqueda global y pseudo-Solis y Wets con búsqueda local, fueron los métodos utilizados en el acoplamiento molecular. Cada simulación consistió en 100 corridas independientes. El resto de los parámetros se establecieron en valores predeterminados. Resultados: La interacción molecular principal entre el ligando y el

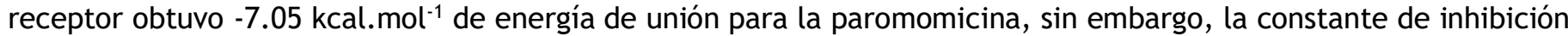
más alta se obtuvo entre la simulación de miltefosina con el receptor, obteniéndose $58.21 \mu \mathrm{M}$ de constante de inhibición. Conclusión: Los resultados revelan una eficacia reducida de los cuatro medicamentos probados en este estudio contra la leishmaniasis, lo que pone de relieve la necesidad de nuevas alternativas bioactivas antileishmania.

Descriptores: Leishmaniasis; Biología Molecular; Simulación del Acoplamiento Molecular.

\section{How to cite:}

Araújo, JL, Bastos RS, Santos GT, Araújo JL, Rocha JA. Evaluation by molecular docking of inhibitors of the enzyme pteridine reductase 1 from Leishmania major. Rev Pre Infec e Saúde [Internet]. 2019;5:9056. Available from: http://www.ojs.ufpi.br/index.php/nupcis/article/view/9056 doi: https://doi.org/10.26694/repis.v5i0.9056

Rev Pre Infec e Saúde. 2019;5:9056 
Araújo JL, et al.

\section{INTRODUCTION}

Leishmaniasis is an endemic disease in more than 98 countries worldwide, with prevalence in areas of tropical climates and underdeveloped countries. ${ }^{1}$ Although we are in the 21 st century, neglected diseases cause public health chaos in several developing countries, due to a lack of basic sanitation and government investment in preventive actions against the parasite. The annual incidence estimates of it reaches 2.5 million cases, with more than 350 million people residing in risk areas. ${ }^{2}$ Leishmaniasis is caused by a kinetoplastid parasite of the Trypanosomatidae family, which belongs to the genus Leishmania.

In Brazil, the cases of Leishmaniasis are observed in almost all the states, with a gradually growth of incidence of both clinical diagnosis forms: American Tegumentary Leishmaniasis (ATL) and Visceral Leishmaniasis $(\mathrm{VL})$. This growth is related to a lack of basic sanitation and the lack of control measures adopted by the Ministry of Health, mainly because ATL does not have a high mortality rate of the and has not received attention of public authorities such as VL, which presents a significant rate of the two infections are among the world's ten most dangerous endemic diseases by the World Health Organization (WHO). ${ }^{3}$ The Leishmania taxonomy is quite complex with thirty species of known leishmaniasis, where 21 species are capable of causing human infection. ${ }^{4}$

Leishmania major is generally responsible for cutaneous leishmaniasis (CL) infection, cause of the infection of 1 million people per year. ${ }^{5}$ It fits into the clinical picture of ATL, and may present itself in three distinct ways: $C L$, which causes simple or multiple sores, usually
Evaluation by molecular docking...

presenting ulcers; Mucocutaneous Leishmaniasis $(M L)$, characterized by the involvement of the oral and nasal mucosae that are destroyed, causing deformations in the individual and may be associated with LC; and, diffuse cutaneous leishmaniasis $(D C L)$, which is characterized by many nodular wounds without ulcerations.

Treatment of the disease comprises of several drugs, such as Pentamidine isethionate, Miltefosine, Paromomycin and Urea Stibamine. All these drugs are potential toxicants, which generate various side effects for people undergoing treatment, in addition to having reduced efficacy against endemic strains, as identified in Nepal, Brazil, India and Africa. ${ }^{6}$ These cases make it clear the need to search for new bioactives such as the evaluation of existing potentials for improvement their biological potential, through studies that measure their rates of leishmanicidal inhibitions. ${ }^{7}$

An alternative to achieve this goal is to explore therapeutic targets essential to the parasite organism or that are sufficient to cause selective inhibition of the organism. $^{8}$ Leishmaniasis species are autotrophic for pteridines, either free or conjugated, allowing the parasite to use pteridines present in the host through a biochemical pathway. ${ }^{9}$ Therefore, organisms that are part of this biochemical pathway of folate recovery become targets in bioactive studies of new compounds with biological potential. ${ }^{10}$

Pteridine Reductase 1 (PTR1) performs the catalytic reduction of biopterin to 7,8dihydrobiopterin, it also enables the catalytic reduction of folate to tetrahydrofolate, in addition to having an important role in the 
Araújo JL, et al.

metacychology of Leishmania species. ${ }^{10}$ Making it an attractive target for antileishmania studies.

Figure 1 shows the three-dimensional model of PTR1 of L. major. The objective of this work is
Evaluation by molecular docking...

to perform a bioactive analysis of L. major Pteridine Reductase 1 inhibitors (LmPTR1) through in silico molecular docking studies.

Figure 1: Three-dimensional model of Leishmania major Pteridine Reductase 1.

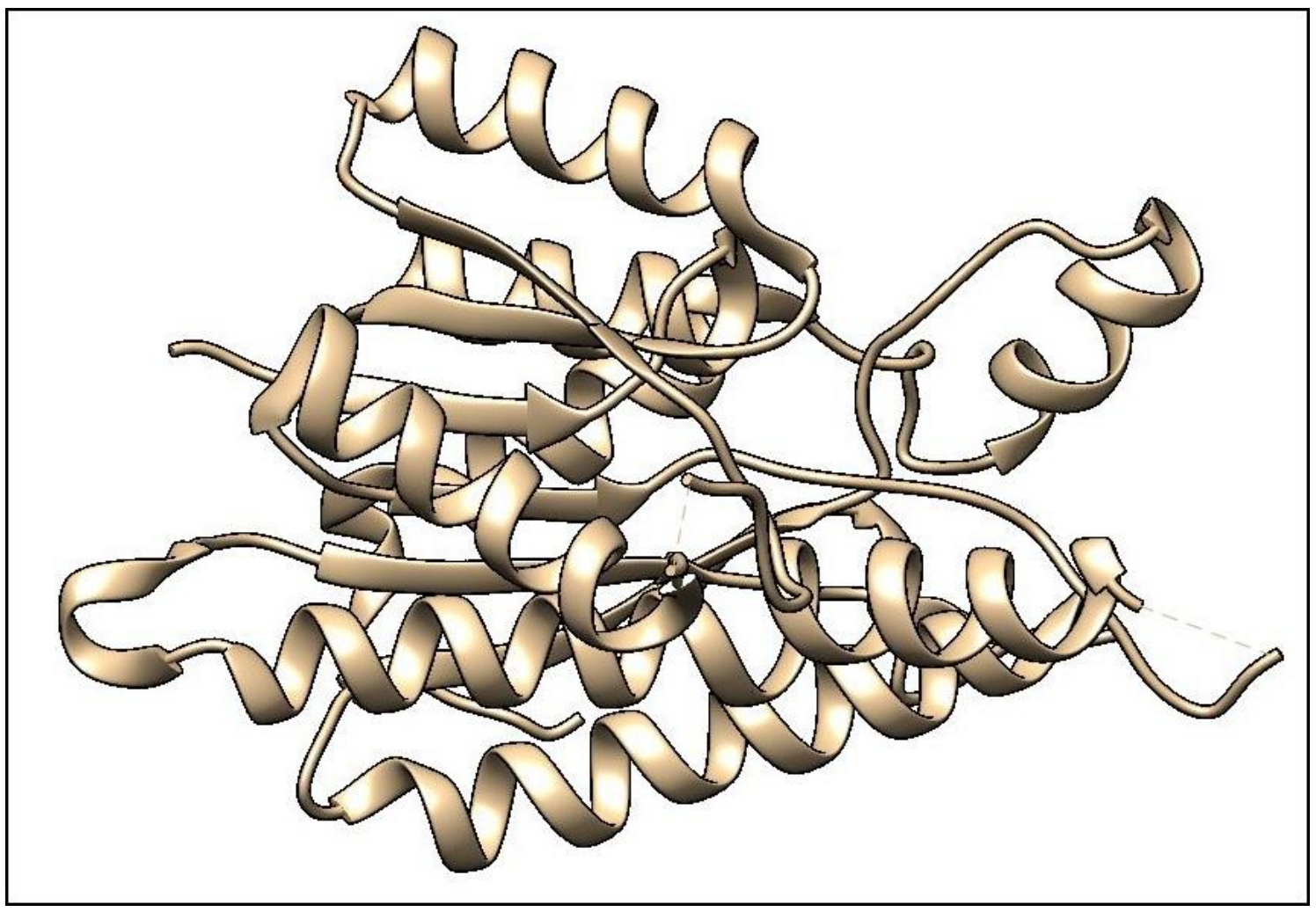

Source: own author, (2019).

\section{METHOD}

The molecular structure of the LmPTR1 in 3D was obtained through the Protein Data Bank (PDB) database with the identification code 5142. The LmPTR1 was prepared using CHIMERA v.13.1 software, removing all water molecules, ions and other residues contained in the molecular structure, as well as the exclusion of the $D, C$ and $B$, leaving only the $A$ chain, in order that the molecular affinity tests can be applied incisively. ${ }^{11}$
The 2D molecular structures of the drugs Pentamidine, Miltefosine, Paromomycin and Urea Estibamine were obtained from the PubChem database and designed in 3D using the GaussView 5.0 software, after molecular optimizations were performed using the Gaussian 16 software in my (c) all Hartree-Fock Default Spin with base 6-31G++(d, p) for each molecular structure of the ligands (Figure 2 ). 
Figure 2: Optimized binders in Hartree-Fock method: a) Paramomycin; b) Urea stibamine; c) Pentamidine isethionate; d) Miltefosine.

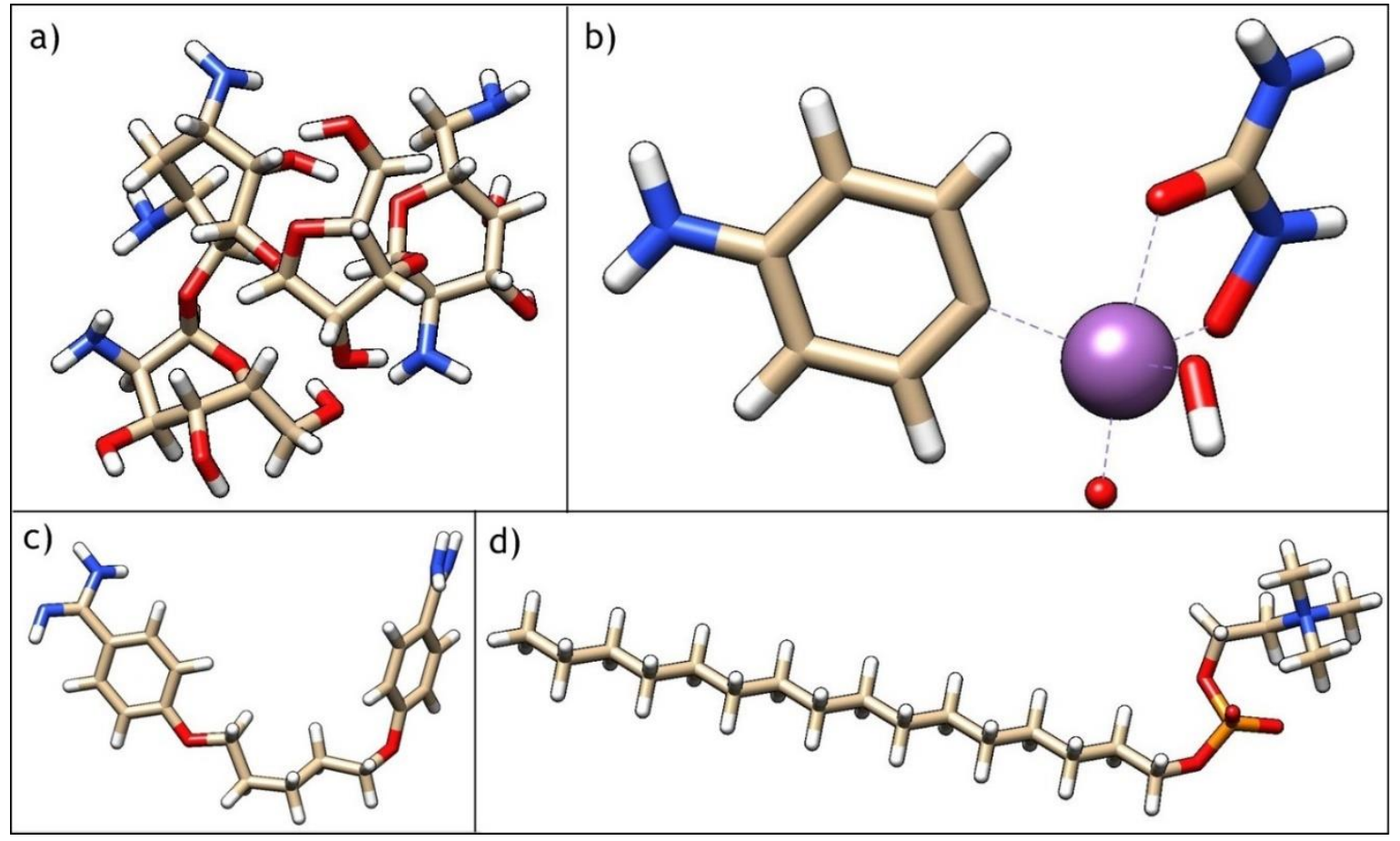

Source: own author, (2019).

Molecular docking was performed using the Autodock Tools (ADT) program, version 1.5.6. ${ }^{12}$ The receiver was considered rigid, while each binder was considered flexible. Gasteiger partial loads were calculated after the addition of all hydrogen. The non-polar hydrogen atoms of proteins and ligands were subsequently blended.

A cubic box of $60 \times 60 \times 60$ points was generated with a resolution of $0.357 \AA$ between the grid points for the receiver's entire target. The molecular affinity grid center was defined from the coordinates of the amino acid Asn109 chain A. The Lamarckian Genetic Algorithm (LGA) with global search and pseudo-Solis and Wets with local search were the methods used in the docking molecular. Each simulation consisted of 100 independent runs, ${ }^{13}$ remainder of the parameters were set to default values.
The molecular affinity analysis focused on the results of lower bond energy, rate of inhibition constant and formation of hydrogen bonds. These data are crucial to evaluate the biological activity of a binder in bioactive action with a receptor through molecular simulation, as it predicts in $95 \%$ confidence the potential that a binder possesses. ${ }^{14}$

\section{RESULTS}

The molecular interaction between paromomycin and LmPTR1 obtained a binding energy of $-7.05 \mathrm{kcal}^{\mathrm{mol}}{ }^{-1}$, as presented in Table 1 , and formed nine hydrogen bonds in amino acids Arg17, Asn109, Asp181, Asp232, Gly19, Gly225 and Ser227, where the amino acids Asp232 and Ser227 make two hydrogen bonds each (Figure 3a). And in the molecular docking between the urea stibamine and the LmPTR1 
Araújo JL, et al.

obtained a result of $-6.13 \mathrm{kcal} . \mathrm{mol}^{-1}$ of binding energy in its molecular affinity parameter and obtaining $31.87 \mu \mathrm{M}$ inhibition constant (Table 1), forming 6 hydrogen bonds in the amino acids Ala15, His36, His38, Lys16 and Ser40, two
Evaluation by molecular docking...

hydrogen bonds being formed in a single amino acid (Ser40). The amino acids Arg17, Arg39, Gly13 and Tyr37 perform the hydrophobic connections near the base of the active site (Figure 3b).

Figure 3: Molecular docking: a) paromomycin bound at the active site of LmPTR1 and their interactions by hydrophobic and hydrogen bonding; b) urea stibamine bound at the active site of LmPTR1 and its interactions by hydrophobic bonds and hydrogen bonds between its amino acids.

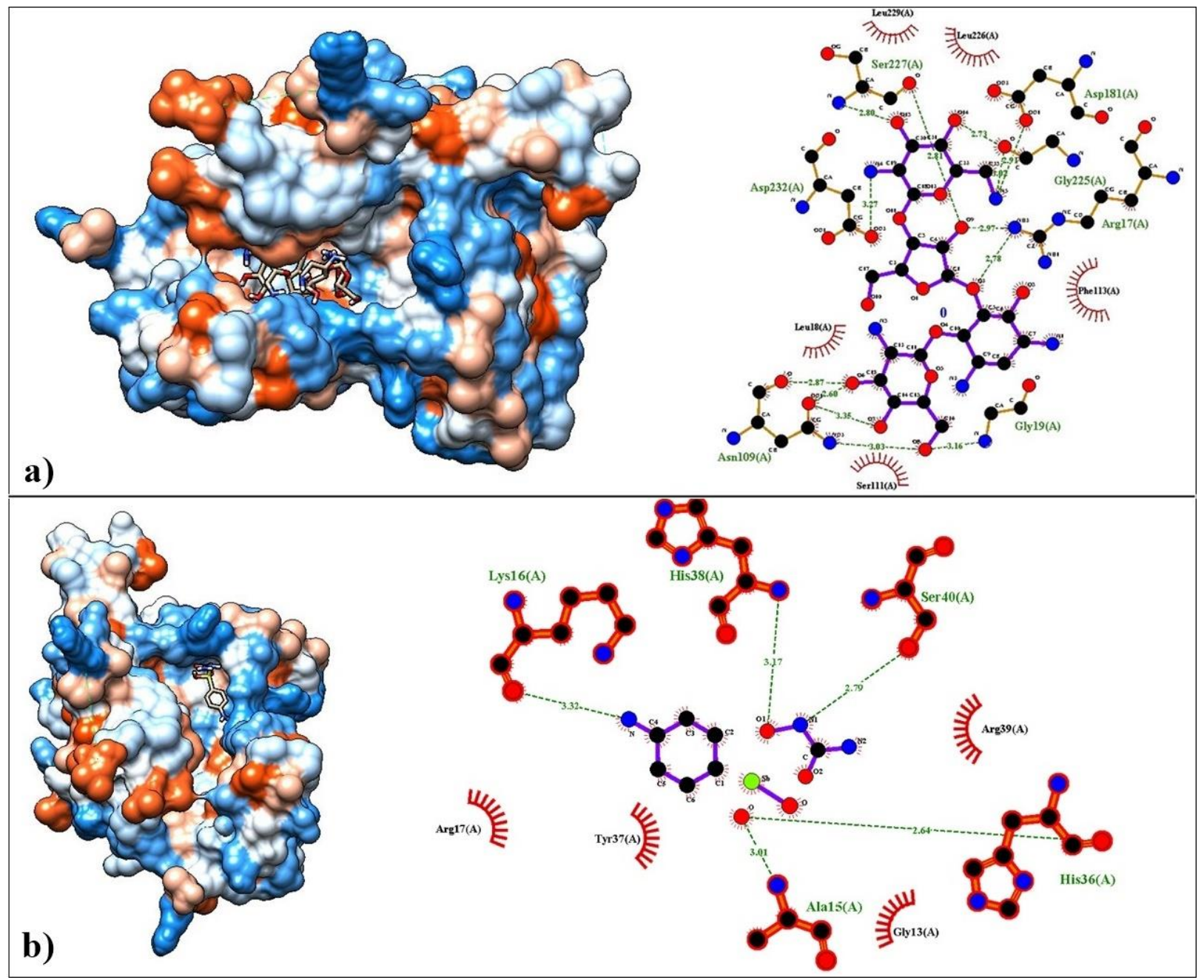

Source: own author, (2019).

Already the molecular interaction between pentamidine isethionate and LmPTR1 obtained a rate of $-6.5 \mathrm{kcal}^{\mathrm{mol}}{ }^{-1}$ of binding energy, showing that the binder has good molecular affinity with the receptor. This interaction resulted in an inhibition constant of
$17.05 \mu \mathrm{M}$ (Table 1). The interaction between the molecular structures formed three hydrogen bonds, located in the amino acids Asn109, Asp65 and Asp142, this place is responsible for containing the most intense interactions of the molecular complex, as well as we can observe 
Araújo JL, et al.

the interactions and distances of each hydrogen bridge connection generated. The amino acids Ala110, Ala64, Arg39, Gly13, His36, His38,
Evaluation by molecular docking...

Leu18, Leu66, Lys16, Ser111, Ser112, Ser146, Ser40, Ser67 and Tyr37 perform the hydrophobic interactions (Figure 4a).

Figure 4: Molecular docking: a) bound pentamidine isethionate in the active site of the LmPTR1 protein and its interactions, by hydrophobic bonds and by hydrogen bonds; b) Miltefosine bound at the active site of the LmPTR1 protein and its interactions, by hydrophobic bonds and by hydrogen bonds between amino acids.

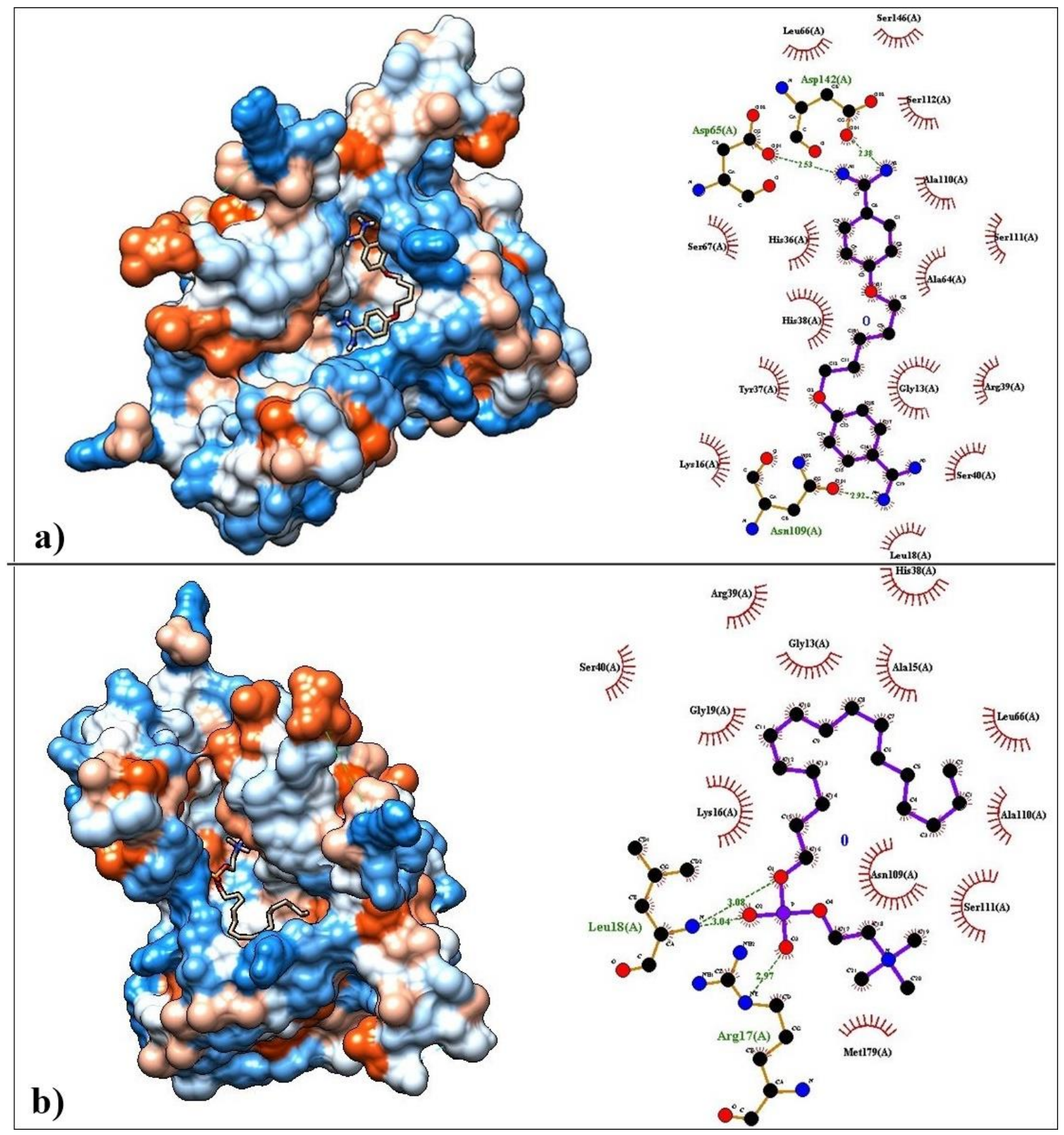

Source: own author, (2019). 
Araújo JL, et al.

Miltefosine was the drug that obtained the lowest molecular affinity with LmPTR1, having a binding energy $-5.78 \mathrm{kcal}^{\mathrm{mol}}{ }^{-1}$, however, it presented with the highest rate of inhibition constant among the drugs evaluated in
Evaluation by molecular docking...

this study, obtaining a rate of $58.21 \mu \mathrm{M}$ (Table 1). The molecular interaction between the ligand and the receptor resulted in two hydrogen bonds located near the LmPTR1 binding site, at amino acids Arg17 and Leu18 (Figure 4b).

Table 1: Parameters of molecular affinity between LmPTR1 and drugs: paromomycin; urea stibamine; pentamidine isethionate; and miltefosine.

\begin{tabular}{|c|c|c|c|c|c|c|}
\hline $\begin{array}{l}\text { Complex } \\
\text { (protein- } \\
\text { binder) }\end{array}$ & $\begin{array}{l}\Delta \mathrm{G}_{\text {bind }}{ }^{\mathrm{a}} \\
\left(\mathrm{kcal}^{-1}\right. \\
\left.\mathrm{mol}^{-1}\right)\end{array}$ & $\begin{array}{l}K^{b} \\
(\mu M)\end{array}$ & $\begin{array}{c}\text { Number of } \\
\text { independent } \\
\text { jumping } \\
\text { races }\end{array}$ & $\begin{array}{c}\text { Number of } \\
\text { conformations } \\
\text { in the first } \\
\text { cluster }\end{array}$ & $\begin{array}{l}\text { Amino Acids that } \\
\text { interact through } \\
\text { Hydrogen Binding }\end{array}$ & $\begin{array}{l}\text { Amino Acids } \\
\text { that perform } \\
\text { Hydrophobic } \\
\text { Interactions }\end{array}$ \\
\hline $\begin{array}{l}\text { Paromomycin/ } \\
\text { LmPTR1 }\end{array}$ & $-7,05$ & 6,83 & 100 & 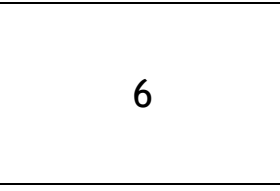 & $\begin{array}{l}\text { Arg17, Asn109, } \\
\text { Asp181, Asp232, } \\
\text { Gly19, Gly225, } \\
\text { Ser227 }\end{array}$ & $\begin{array}{c}\text { Leu18, Leu226, } \\
\text { Leu229, } \\
\text { Phe113, Ser111 }\end{array}$ \\
\hline $\begin{array}{c}\text { Urea } \\
\text { stibamine/ } \\
\text { LmPTR1 }\end{array}$ & $-6,13$ & 31,87 & 100 & 4 & $\begin{array}{l}\text { Ala15, His36, } \\
\text { His38, Lys16, Ser40 }\end{array}$ & $\begin{array}{l}\text { Arg17, Arg39, } \\
\text { Gly13, Tyr37 }\end{array}$ \\
\hline $\begin{array}{c}\text { Pentamidine } \\
\text { isethionate/ } \\
\text { LmPTR1 }\end{array}$ & $-6,5$ & 17,05 & 100 & 6 & $\begin{array}{c}\text { Asn109, Asp65, } \\
\text { Asp142 }\end{array}$ & $\begin{array}{c}\text { Ala110, Ala64, } \\
\text { Arg39, Gly13, } \\
\text { His36, His38, } \\
\text { Leu18, Leu66, } \\
\text { Lys16, Ser111, } \\
\text { Ser112, Ser146, } \\
\text { Ser40, Ser67, } \\
\text { Tyr37 }\end{array}$ \\
\hline $\begin{array}{l}\text { Miltefosine/ } \\
\text { LmPTR1 }\end{array}$ & $-5,78$ & 58,21 & 100 & 9 & Arg17, Leu18 & $\begin{array}{l}\text { Ala110, Ala15, } \\
\text { Arg39, Asn109, } \\
\text { Gly13, Gly19, } \\
\text { His38, Leu66, } \\
\text { Lys16, Met179, } \\
\text { Ser111, Ser40 }\end{array}$ \\
\hline
\end{tabular}

\section{DISCUSSION}

Among the drugs evaluated, paromomycin has the best molecular interaction with the protein LmPTR1 even being a drug used for LV treatments we see its inhibitory action in a rather important protein in the metacyclogenesis paper of the Leishmaniasis of the Leishmania major genus, with an inhibition constant rate of $6.83 \mu \mathrm{M}$. A very high inhibitory action compared to some studies in the literature. ${ }^{15}$ Showing that paromomycin in reaction with 6'-N-acetyltransferase has an Rev Pre Infec e Saúde. 2019;5:9056 inhibition rate of $1.23 \mu \mathrm{M}$, a rate below that reported in reaction with LmPTR1. The threedimensional image illustrating the molecular docking between paromomycin and LmPTR1 is shown in Figure 3a.

The literature presents urea stibamine as one of the best alternatives for the treatment of Leishmaniasis, among them $L$. donovani. ${ }^{16}$ When we compare results of inhibition constant in different species of Leishmania, we noticed that the drug has efficacy activity with LmPTR1, having an inhibition constant of $31.87 \mu \mathrm{M}$, while 
Araújo JL, et al.

the same drug in reaction with a $L$. donovani type I topoisomerase DNA enzyme exhibits an inhibition constant of $40 \mu \mathrm{M} .{ }^{17}$ This is related to molecular affinity between the ligand and the macromolecule, which in addition to possessing bioactive potential antileishmania has good molecular affinity with the receptor. The difference in inhibition constants among drugs may be related to the resistance of strains and the distinct characteristics of each species of Leishmania. The three-dimensional image illustrating the molecular docking between the urea scaffin and the LmPTR1 is shown in Figure $3 b$.

Studies of the biological potential of pentamidine antileishmania isethionate, through in vitro assays in promastigotes and amastigotes of $L$. donovani, show an action inhibition of 8.31 $\mu \mathrm{M}$ for promastigote forms and $2.7 \mu \mathrm{M}$ for amastigote forms. ${ }^{18}$ We can observe that the same drug being indicated for VL treatments has activity against $L$. major species, through these in silico studies by molecular docking, we obtain favorable results showing the drug as a possible alternative against $L$. major species. The in silico studies presented a rate of inhibition constant higher than the values presented in an in vitro study, where we can observe the biological activity of the same drug in different species of Leishmania. The three-dimensional image illustrating the molecular docking of pentamidine isethionate at the active site of LmPTR1 is shown in Figure 4a.

Miltefosine was the first oral drug approved in India, having a 94\% efficacy rate in L. donovani treatments, but this rate was reduced to $60 \%$, this is related to the increase of
Evaluation by molecular docking...

resistance of strains and the specific characteristics of the parasite. ${ }^{19}$ In vivo studies showed the reduced efficacy of the inhibitory potential of miltefosine in treatment with mice infected with L. amazonenses strains during 100 days of leishmanicide evaluation using 20 $\mathrm{mg} / \mathrm{kg} /$ day of miltefosine and the presence of amastigotes intracellular amastigotes in the organism within 100 days of treatment, its efficacy was only observed after 250 days posttreatment in the mouse organism, increasing the concentration to 30,40 and $50 \mathrm{mg} / \mathrm{kg} /$ day. The clinical cure of mice infected with $L$. donovani strains at concentrations of 30,40 and $50 \mathrm{mg} / \mathrm{kg} /$ day after 250 days of treatment was confirmed in qPCR analyzes. ${ }^{20}$

\section{CONCLUSION}

It was evidenced that the drugs evaluated in this study are having reduced efficacy in treatments of Leishmania sp, this is related to the resistance of strains and the distinct characteristics of each species. The drugs that presented considerable inhibition constant results against Leishmania major genus species were stibamine urea with $31.87 \mu \mathrm{M}$ and miltefosine with $58.21 \mu \mathrm{M}$ inhibition constant, presenting them as possible alternatives in treatments of species of Leishmania major, and not only being applied in VL treatments.

With these results, we emphasize the need to search for new alternatives of antileishmania bioactive compounds, whether they are provided with natural or synthetic resources. We also emphasize the importance of insole studies of rational planning of drugs already available and available in the industry, 
Araújo JL, et al.

performing studies that predict sites in chemical structures that can be modified or replaced by
Evaluation by molecular docking...

other chains or organic compounds to further increase their biological potential.

\section{REFERENCES}

1. Alvar J, Vélez I, Berna C, Herrero M, Desjeux $\mathrm{P}$, Cano J, et al. Leishmaniasis worldwide and global estimates of its incidence. Plos one [Internet]. 2012 [cited 2019 May 16]; 7(5):1-9. Available from: https://doi.org/10.1371/journal.pone.0035671

2. Queiroz MJA, Alves JGB, Correia JB. Leishmaniose visceral: características clínicoepidemiológicas em crianças de área endêmica. J Pediatr [Internet]. 2004 [cited 2019 May 16]; 80(2):141-146. Available from: http: / /dx.doi.org/10.1590/S0021-

75572004000200012

3. Dujardin JC. Risk factors in the spread of leishmanioses: towards integrated monitoring. Trend Parasitol [Internet]. 2006 [cited 2019 May 16]; 22(1):4-6. Available from: https://doi.org/10.1016/j.pt.2005.11.004

4. Ashford RW. The Leishmaniasis as emerging and reemerging zoonoses. International Journal for Parasitology [Internet]. 2000 [cited 2019 May 18]; 30:1269-1281. Available from: https://doi.org/10.1016/S0020-7519(00)00136-3

5. Bennis I, Brouwere V, Ameur B, Laamrani AE, chichaoui S, Hamid S, et al. Control of cutaneous leishmaniasis caused by Leishmania major in South-eastern Morocco. Trop Med Int Health [Internet]. 2015 [cited 2019 May 18]; 20(10):1297-1305. Available from: https://doi.org/10.1111/tmi.12543

6. Sundar S, Chakravarty J. Antimony toxicity. Int. J. Environ. Res. Public Health [Internet].
2010 [cited 2019 May 18]; 7(12):4267-4277. Available from: https://doi.org/10.3390/ijerph7124267

7. Tiuman TS, Santos AO, Ueda-Nakamura T, Filho BPD, Nakamura CV. Recent advances in leishmaniasis treatment. Int $\mathrm{J}$ Infect Dis [Internet]. 2011 [cited 2019 May 18]; 15(8):525532. Available from: https://doi.org/10.1016/j.ijid.2011.03.021

8. Azevedo WF, SOARES MBP. Selection of targets for drug development against protozoan parasites. Curr Drug Targets [Internet]. 2009 [cited 2019 May 19]; 10(3):193-201. Available from:

https://doi.org/10.2174/138945009787581186

9. Kumar P, Kumar A, Verma SS, Dwivedi N, Singh $\mathrm{N}$, Siddiqi MI, et al. Leishmania donovani pteridine reductase 1: biochemical properties and structure-modeling studies. Exp. Parasitol [Internet]. 2008 [cited 2019 May 19]; 120(1):7379. Available from: https://doi.org/10.1016/j.exppara.2008.05.005 10. Cunningham ML, Beverley SM. Pteridine salvage throughout the Leishmania infectious cycle: implications for antifolate chemotherapy. Mol Biochem Parasitol [Internet]. 2001 [cited 2019 21]; 113(2):199-213. Available from: https://doi.org/10.1016/S0166-6851(01)00213-4 11. Pettersen EF, Goddard TD, Huang CC, Couch GS, Greenblatt DM, Meng EC, et al. UCSF Chimera-a visualization system for exploratory research and analysis. J Comput Chem 
Araújo JL, et al.

[Internet]. 2004 [cited 2019 May 21]; 25:16051612.

Available

from:

https://doi.org/10.1002/jcc.20084

12. Morris GM, Huey R, Olson AJ. Using AutoDock for ligand-receptor docking. Curr. Protoc. Bioinformatics [Internet]. 2008 [cited 2019 May 21]; 24(1):8.141-8.1440. Available from: https://doi.org/10.1002/0471250953.bi0814s24

13. Ramos RM, Perez JM, Baptista LA, Amorim HLN. Interaction of wild type, G68R and L125M isoforms of the arylamine- $\mathrm{N}$-acetyltransferase from Mycobacterium tuberculosis with isoniazid: a computational study on a new possible mechanism of resistance. J Mol Model [Internet]. 2012 [cited 2019 May 21]; 18(9):4013-4024. Available from: https://doi.org/10.1007/s00894012-1383-6

14. Rocha JA, Rego NCS, Carvalho BTS, Silva FI, Sousa JA, Ramos RM, et al. Computational quantum chemistry, molecular docking, and ADMET predictions of imidazole alkaloids of Pilocarpusmicrophyllus with schistosomicidal properties. PloS one [Internet]. 2018 [cited 2019 may 22]; 13(6):1-9. Available from: https://doi.org/10.1371/journal.pone.0198476

15. Zhu L, Liu R, Liu T, Zou X, Xu Z, Guan H. A novel strategy to screen inhibitors of multiple aminoglycoside-modifying enzymes with ultrahigh performance liquid chromatographyquadrupole-time-of-flight mass spectrometry. J Pharm Biomed Anal [Internet]. 2019 [cited 2019 May 22]; 164:520-527. Available from: https://doi.org/10.1016/j.jpba.2018.11.021

Submitted: 2019-06-26

Accepted: 2019-08-12

Published: 2019-11-01
Evaluation by molecular docking...

16. Chakraborty AK, Majumder HK. Mode of action of pentavalent antimonials: Specific inhibition of type I DNA topoisomerase of Leishmaniadonovani. Biochem. Biophys. Res. Commun [Internet]. 1988 [cited 2019 May 24]; 152(2):605-611. Available from: https://doi.org/10.1016/S0006-291X(88)80081-0 17. Riou G, Douc-rasy S, Kayser A. Inhibitors of trypanosome topoisomerases. Biochem Soc Trans [Internet]. 1986 [cited 2019 May 24]; 14(2):496499. Available from: https://doi.org/10.1042/bst0140496

18. Ashok P, Chander S, Smith TK, Singh RP, Jha PN, Sankaranarayanan M. Biological evaluation and structure activity relationship of 9-methyl-1phenyl-9H-pyrido [3, 4-b] indole derivatives as anti-leishmanial agents. Bioorg Chem [Internet]. 2019 [cited 2019 May 24]; 84:98-105. Available from:

https://doi.org/10.1016/j.bioorg.2018.11.037

19. Carnielli JBT, Crouch K, Forrester S, Silva VC, Carvalho SFG, Damasceno JD, et al. A Leishmania infantum genetic marker associated with miltefosine treatment failure for visceral leishmaniasis. EBioMedicine [Internet]. 2018 [cited 2019 May 25]; 36:83-91. Available from: https://doi.org/10.1016/j.ebiom.2018.09.029

20. Godinho JLP, Rodrigues CS, Silva R, Urmenyi TP, Souza W, Rodrigues JCF. Efficacy of miltefosine treatment in Leishmania amazonensis-infected BALB/C mice. Int J Antimicrob Agents [Internet]. 2012 [cited 2019 May 25]; 39(4):326-331. Available from: https://doi.org/10.1016/j.ijantimicag.2011.11.0 08 


\section{COLLABORATIONS}

AAC: Substantial Contributions in the research conception and design; data analysis and interpretation; in the critical review of the article and in the final version to be published. JLA, RSB, GTS, JLA and JAR: substantial contributions to data collection, analysis and interpretation; in the writing of the article; and in the final version to be published. All authors agree and are responsible for the contents of this version of the manuscript to be published.

\section{ACKNOWLEDGMENTS}

Not applicable.

\section{AVAILABILITY OF DATA}

Not applicable.

\section{FUDING SOURCE}

Not applicable.

\section{CONFLICTS OF INTEREST}

No conflicts of interest to declare.

\section{CORRESPONDENCE}

Joabe Lima Araújo

Address: Aurila Maria Santos Barros de Sousa, s/n, Loteamento Frei Alberto Beretta, Grajaú - MA, CEP: 65940-000, Brazil.

Telephone: +55 (99) 99953-9446

E-mail: joabearaujobiotec@gmail.com 